\section{Invasive Plants with Native Lookalikes: How Mistaken Identities Can Lead to More Significant Plant Invasions and Delay Management}

\author{
S. Christopher Marble ${ }^{1}$ and Stephen H. Brown ${ }^{2}$
}

\begin{abstract}
Additional Index words. Commelina, Florida, Praxelis, Ruellia, Solanum, Tradescantia

Summary. Plant invasions pose a serious threat to biodiversity, agricultural production, and land value throughout the world. Due to Florida's unique climate, population expansion, expansive coastline, and number of seaports, the state is especially vulnerable to non-native plant naturalization and spread. Invasive plant management programs were shown to have higher success rates with fewer resources when invasives were managed soon after non-native plants were observed. However, some newly emerging invasive plants may go undetected due to their resemblance with native species or other invasive plants. The objective of this review is to highlight a few key invasive plants in Florida that have native lookalikes. While morphological differences are discussed, the primary goal is to discuss management implications of misidentification and delayed response times, as well as the need for plant identification guides that include information on how to distinguish problematic invasive plants from similar native species.
\end{abstract}

T he ecological and economic impacts of invasive plants are well documented and were thoroughly synthesized previously (Kettenring and Adams, 2011; Pysek et al., 2012; Weidlich et al., 2020). From an ecological standpoint, invasive plants reduce the prevalence and establishment of native species, interfere with natural ecological properties such

Received for publication 30 Jan. 2021. Accepted for publication 12 Mar. 2021.

Published online 2 June 2021.

${ }^{1}$ Environmental Horticulture Dept, Mid-Florida Research and Education Center, Institute of Food and Agricultural Sciences, University of Florida, 2725 S. Binion Road, Apopka, FL 32703

${ }^{2}$ Lee County Extension, Institute of Food and Agricultural Sciences, University of Florida, 3410 Palm Beach Boulevard, Fort Myers, FL 33916

This article was presented as part of the Invasive Plants Research Professional Interest Group workshop entitled "Progress in Identification and Control of Weedy to Invasive Plants both Domestic and Abroad" held on 12 Aug. 2020 during the virtual American Society for Horticultural Science's annual conference. We thank Annette Chandler, Roger L. Hammer, Walter K. Bradley, and Kaylynn Low for their expertise and use of their photographs.

S.C.M. is an Assistant Professor.

S.H.B. is an Extension Agent IV.

S.C.M. is the corresponding author. E-mail: marblesc@ufl.edu.

This is an open access article distributed under the CC BY-NC-ND license (https://creativecommons. org/licenses/by-nc-nd/4.0/).

https://doi.org/10.21273/HORTTECH04821-21 as nutrient cycling or hydrology, and reduce wildlife resources including food and habitat (Pysek et al., 2012; Weidlich et al., 2020). On a global economic standpoint, billions of dollars are spent annually managing invasive plants, with some estimates of $\sim \$ 40$ billion annually in the United States alone (Diagne et al., 2020; Pimentel et al., 2005).

Several plant characteristics were established as attributes that facilitate or predict of invasiveness. High seed viability (Wickert et al., 2017), rapid growth rates (Kleunen et al., 2010), short juvenile period (Rejmanek and Richardson, 1996), efficient resource allocation [e.g. light, nutrients, water (Liu and Zhu, 2018)], genetic plasticity (Ren and Zhang, 2009; VanWallendael et al., 2018), and reduced or absence of natural predators in an introduced range (Heckman et al., 2017; Keane and Crawley, 2002) may all lead to plants becoming successful invaders (El-Barougy et al., 2020;
Holzmueller and Jose, 2009). As such, these traits are typically evaluated as part of risk assessments that can aid stakeholders in predicting a plant's invasive potential (Anderson et al., 2004; Randall et al., 2008).

Plant invasions occur in stages often classified as introduction, establishment, and spread (Alvarez and Solis, 2018). During the invasion process, there is often a lag time, or delay, from when the species becomes established until it expands exponentially. Lag times may be brief or last multiple decades, with a plant becoming invasive due to anthropogenic or natural changes in the environment or climate. Examples of changes that could result in rapid expansion would include climate change, hybridizations, deforestation or removal of native species, introduction of dispersal vectors, or multiple introduction events, among other catalysts (Daehler, 2009; Mack et al., 2000; Osland and Feher, 2020; Petitpierre et al., 2017). Lag effects are not well understood, partially because they are often species and environmentally specific. Crooks and Soule (1996) noted that many estimates of the time between initial introduction and population explosion are likely conservative due to an additional lag effect, which is our ability to detect the presence of a new invasive species. While there is a need to increase public awareness and knowledge of the presence and impact of invasive plants in general (Daab and Flint, 2010; Oxley et al., 2016; Waliczek et al., 2018), one aspect of invasive plant detection is distinguishing harmful invasive plants from native plants when they look alike. Instances may also arise where a newly emerging invasive plant is similar in appearance to an already naturalized invasive, which also may delay detection and response before the new invader becomes more widespread and or problematic. The objective of this review is to highlight newly emerging and some established invasive plants that are often confused with native lookalikes in Florida. While biological and morphological differences are summarized, the primary

\begin{tabular}{llll}
\hline $\begin{array}{l}\text { Units } \\
\text { To convert U.S. to SI, } \\
\text { multiply by }\end{array}$ & U.S. unit & SI unit & $\begin{array}{l}\text { To convert SI to U.S., } \\
\text { multiply by }\end{array}$ \\
\hline 0.4047 & acre $(\mathrm{s})$ & ha & 2.4711 \\
0.3048 & $\mathrm{ft}$ & $\mathrm{m}$ & 3.2808 \\
2.54 & inch(es) & $\mathrm{cm}$ & 0.3937
\end{tabular}


focus is to highlight management implications and the need for extension and outreach materials to include information that help land managers and the public to distinguish harmful from harmless plants.

\section{Impact of invasive plants in Florida}

Plant invasions are prevalent in Florida due to many factors, including the state's unique climate ranging from temperate to sub-tropical, peninsular geography, multiple shipping ports, and diversity of horticultural and agricultural industries (Hiatt et al., 2019). Close to 1500 non-native plant species have been documented as established in Florida (Wunderlin et al., 2021). The Florida Invasive Species Council (FISC), formerly known as the Florida Exotic Plant Pest Council (FLEPPC), is a nonprofit, nonregulatory agency with the mission of supporting management of invasive plants by providing a forum for the exchange of scientific, educational, and technical information. As part of their mission, FISC publishes a list of invasive plants in Florida, categorizing species as Category 1 (alternative native plant communications, changing ecological functions, hybridizing with natives) or Category 2 (increased in abundancy and frequency, but not yet altered Florida plant communities). There are now 81 and 84 species ranked as Category 1 and 2 , respectively, with more species becoming naturalized and increasing in abundance, potentially posing a significant future threat (Florida Exotic Plant Pest Council, 2019). In the agricultural sector, invasive plants are financially costly and have resulted in losses of $\$ 180$ million.

In natural areas, Hiatt et al. (2019) reported that about $\$ 45$ million was spent annually in Florida on invasive plant management. Notably, the bulk of resources was spent on management of hydrilla (Hydrilla verticillata), water hyacinth (Eichhornia crassipes), melaleuca (Melaleuca quinquenervia), brazilian pepper (Schinus terebinthifolia), and old-world climbing fern (Lygodium micropbyllum). These species can be especially damaging from an ecological and economic standpoint due to their fast growth and reproduction rates along with their tendency to invade vulnerable ecosystems or waterways. For example, the aquatic weeds hydrilla and water hyacinth, introduced from Asia and South America, respectively, reduce water flow in drainage and irrigation canals, impede navigation of watercraft, and may reduce water oxygen levels and consequently reduce fish populations, not to mention displacement of many native aquatic species (Langeland, 1996; Villamagna and Murphy, 2010). Native to Australia, melaleuca trees are perfectly adapted to south Florida's climate. Due to copious seed production, a fast growth rate, the ability to tolerate burning, and lack of natural predators, melaleuca trees can form dense stands in the Florida Everglades and completely alter ecosystems (Turner et al., 1998). One report showed that melaleuca increased in coverage to $95 \%$ in sawgrass (Cladium jamaicense) prairies within 25 years after an initial infestation cover of only $2 \%$ to $5 \%$ (Laroche and Ferriter, 1992). Brazilian pepper is native to South America (i.e., Brazil, Argentina, and Paraguay) and following introduction, it spread throughout the Florida peninsula and is now considered to be one of the most serious invasive plants in the state. It has been estimated that over 280,000 ha of south and central Florida are invaded by brazilian pepper due to high seed production, viability, bird dispersal, tolerance to many different environmental conditions (drought, fire, shade), and potentially having allelopathic effects on other plant species (Overholt et al., 2012; Panetta and McKee, 1997). Old-world climbing fern is native to Asia and Australia but has overtaken many parts of south Florida. Due to its climbing growth habit, it can grow over trees and shrubs and completely smother entire plant communities (Pemberton and Ferriter, 1998). In most cases, resources such as funding for research and management are naturally going to be allocated more toward these most problematic invasive and prevalent invasive plant species (Hiatt et al., 2019; Pysek et al., 2012; Weidlich et al., 2020). Species that are already established and causing economic and or ecological harm necessitate the need for continual action. However, from a management standpoint, control and eradication efforts are more successful and less costly when implemented early in the invasion process (Alvarez and Solis, 2018). Therefore, it is especially important to identify new and emerging invasive plants during their lag period and begin control efforts before wide-scale naturalization, as proposed by Crooks and Soule (1996).

\section{Issues associated with invasive plant monitoring}

Early detection of invasive plant species and rapid management response is the optimum approach in preventing the establishment of invasive plants (Maxwell et al., 2009). Currently, invasive plant monitoring and reporting is accomplished using several approaches. Traditionally, field observations and aerial surveys are conducted by private landowners, state agencies, and other organizations to monitor and detect invasive plant distributions (Foxcroft et al., 2008). While accurate and effective, these traditional methods of monitoring are not sustainable in many instances because of the associated time and expense on a large-scale basis. In many areas, these traditional monitoring methods may also be hampered by access to remote regions (Royimani et al., 2019). Currently, monitoring is often carried out using remote sensing technologies such as footage captured from unmanned aerial vehicles (Papp et al., 2021). Remote sensing solves the issues of labor and access to remote areas; but while numerous technological advancements have been made, remote sensing monitoring efforts may be limited by challenges such as cost, technical expertise, and may be limited to species that have a unique spectral signature or those species with a dominant canopy structure (Rodgers et al., 2017).

As invasive plants invade many different environments across large temporal and spatial scales, it is difficult to intensely monitor their spread or note the emergence of new invasive plants due to the challenges described previously. Citizen science programs and similar efforts in which volunteers can report or map the spread of invasive plants can be a means of gathering these data in an economical fashion (Jordan et al., 2012). With certain plant species, minimally trained volunteers were shown to be as accurate as professionals when identifying to the genus level (Brandon et al., 2003). The data that volunteers can add may be valuable and improve accuracy of distribution maps 
and help prioritize management efforts (Crall et al., 2015). However, there has been hesitation to use data generated by minimally trained professionals due to concerns over data quality (Bonter and Cooper, 2012). MacKenzie et al. (2017) reported that plant species that were most likely to be misidentified were less conspicuous species that were lower in abundance, whereas plants that were found frequently across many different sites were identified correctly over $98 \%$ of the time. These research observations indicated that invasive plants can proliferate in new areas and go undetected, and the risk of this happening may increase when the plant is not widely distributed in a new area and is similar in appearance to native species (Verloove, 2010). In Florida, several newly emerging or established invasive plants are regularly misidentified as natives or other introduced species, a situation that could either possibly lead to delays in control or may have already done so. Overall, any invasive species could be misidentified or confused with a similar species. However, based upon previous reports (Abbott et al., 2008), as well as extension-based informal surveys, some notable invasives often confused with native plants or noninvasive introduced ornamentals in Florida include praxelis (Praxelis clematidea), hairyflower wild petunia (Ruellia ciliatiflora), twoleaf nightshade (Solanum dipbyllum), and multiple spiderwort (Tradescantia) and dayflower (Commelina) species.

\section{Praxelis: An emerging weed confused with native and other invasive plants}

Praxelis is an annual or short-lived perennial herb native to South America and was introduced to many tropical and subtropical areas worldwide, including

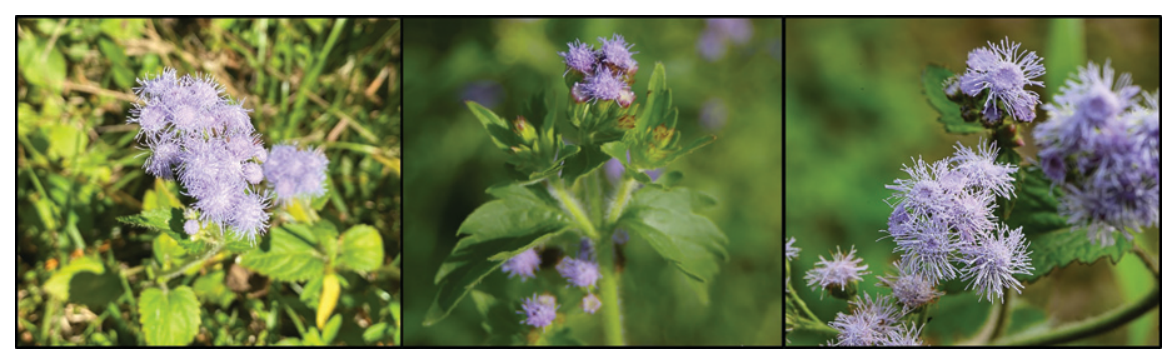

Fig. 1. Flowers of the Florida native blue mistflower (left) in comparison with the invasive praxelis (center) and bluemink (right). (Photo credits: blue mistflower, Kaylynn Low; praxelis, Annette Chandler; bluemink, Roger L. Hammer.)

China, Taiwan, and throughout Australia (King and Robinson, 1970; Waterhouse, 2003). In the United States, it has only been documented in Florida, first being discovered in Orange County in 2006 (Abbott et al., 2008). Praxelis is a model example of an introduced invasive plant that went undetected for years because it is so similar in morphology to a Florida native species and other naturalized introduced weeds (Abbott et al., 2008 ). First, praxelis is similar to the Florida native blue mistflower (Conoclinium coelestinum), siamweed (Chromolaena odorata), and pink thoroughwort (Fleischmannia incarnata). These species can be similar in size and have small clusters of lilac-to-bluish-purple flowers that are superficially similar in appearance. As noted by Gardner and Williges (2015), praxelis has a strongly conical receptacle, differentiating it from Florida native species. Praxelis more strongly resembles two other invasives in Florida, including tropical whiteweed (Ageratum conyzoides) and bluemink (Ageratum houstonianum) (Fig. 1). Confusion of praxelis with tropical whiteweed and bluemink, both naturalized non-native weeds, has occurred elsewhere, delaying treatment in Queensland, Australia, and Hong Kong (Corlett and Shaw, 1995; Waterhouse, 2003). Some differentiating characteristics would include that tropical whiteweed and bluemink lack a pappus, whereas praxelis has one. Abbreviated botanical keys have been previously published differentiating praxelis from other non-native weeds and Florida native species, which can aid in identification efforts (Abbott et al., 2008). Additionally, other characteristics could be used, such as the fact that praxelis has irregularly serrated margins and a strong odor when the leaves are crushed that has been described as smelling like cat urine (Gardner and Williges, 2015). Although more

Hortlechnology • August 2021 31(4) information is now available on praxelis identification and management (Khamare et al., 2020), it has continued to spread throughout central Florida. However, it is unknown if the increased prevalence is due to newfound awareness or due to rapid expansion of praxelis.

\section{Wild petunia (Ruellia): Native species among the invasives}

There are currently nine species of wild petunia that have been vouchered in Florida, of which five are native to the state, including carolina wild petunia (Ruellia caroliniensis), ciliate wild petunia ( $R$. ciliosa), nightflowering wild petunia ( $R$. noctiflora), stalked wild petunia ( $R$. pedunculata), and thickleaf wild petunia $(R$. succulenta) (Freyre and Tripp, 2014; Wunderlin et al., 2021). Four non-native species can be found in Florida, including green shrimp plant $(R$. blechum), hairyflower wild petunia $(R$. ciliatiflora), shrubby wild petunia $(R$. dipteracanthus), and mexican petunia (R. simplex) - with shrubby wild petunia occurring very rarely (only vouchered in one county) and mexican petunia being categorized as a Category 1 invasive by FISC with a distribution throughout Florida and other southeastern states (Wunderlin et al., 2021). Mexican petunia is by far the most invasive and widely distributed of the wild petunia species in Florida, and the invasive nature and ecological impact of mexican petunia has been well documented in previous reports (Freyre and Tripp, 2014; Wiese et al., 2013; Wilson et al., 2004). It was first introduced as an ornamental but is no longer recommended for landscape use due to its propensity of spread, resulting from its ability to tolerate a wide range of conditions, high seed production and viability, and spread via rhizomatous growth (Freyre and Tripp, 2014). Because it was and is still such a popular landscape plant, sterile cultivars have been developed and released that lack invasive tendencies (Freyre et al., 2012).

While mexican petunia is the most problematic of the invasive wild petunia species, it is somewhat easy to identify compared with native species because of its taller and more upright growth habit, longer linear leaves, and more vigorous growth compared with the native carolina wild petunia. While 


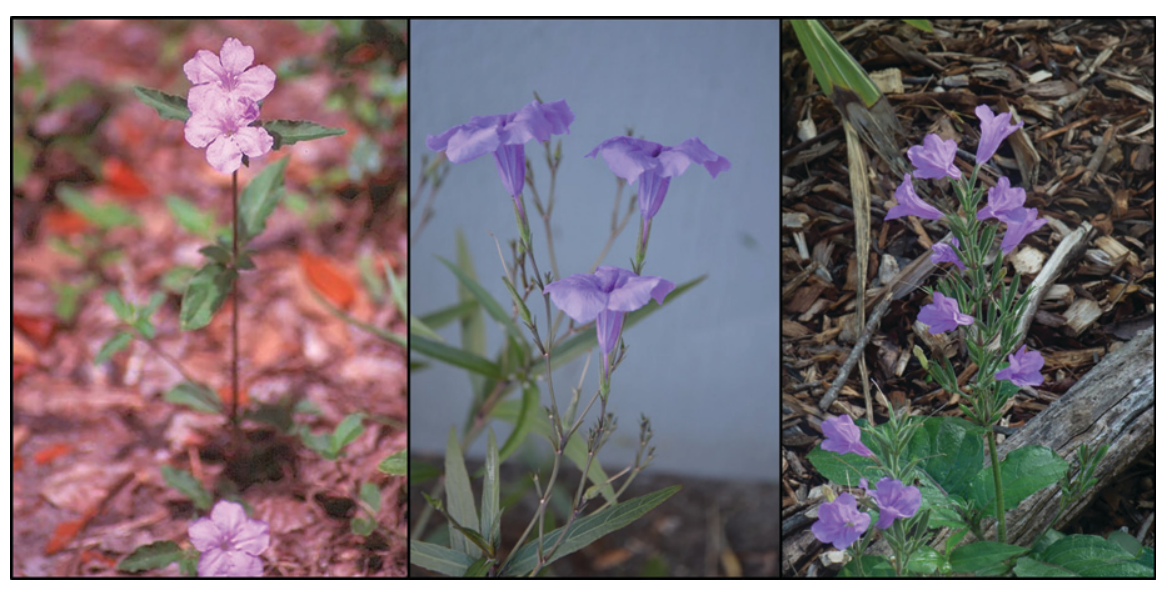

Fig. 2. Flowers of the Florida native carolina wild petunia (left) in comparison with invasive mexican petunia (center) and hairyflower wild petunia (right). (Photo credits: carolina wild petunia, Walter K. Bradley; mexican petunia, Stephen H. Brown; hairyflower wild petunia, Roger L. Hammer.)

not nearly as problematic or widespread, hairyflower wild petunia has naturalized in at least five counties throughout the state and has been frequently cited as a nuisance weed in managed landscapes (S.C. Marble, unpublished data). Hairyflower wild petunia is also more likely to be confused because it closely resembles native species, specifically the carolina wild petunia. Carolina wild petunia is an upright perennial with a height of 31 to $52 \mathrm{~cm}$, has oval leaves 6.7 to $7.5 \mathrm{~cm}$ long, and bluish-purple tubular flowers throughout the summer (Wilson et al., 2004). In contrast, hairyflower wild petunia is often taller and more upright (up to $80 \mathrm{~cm}$ in height), and it has ovate-shaped leaves slightly larger than carolina wild petunia (up to $13 \mathrm{~cm}$ long and $8 \mathrm{~cm}$ wide). The primary means of differentiation in the field is the dense pubescence on hairyflower wild petunia (Ward, 2007). Many of the wild petunia species are notoriously difficult to identify based on traditional morphological characteristics (Long and Uttal, 1962), thus it is possible that hairyflower wild petunia and other introduced wild petunia species may have a wider distribution than is currently documented (Fig. 2).

\section{Twoleaf nightshade: An emerging invasive shrub}

Twoleaf nightshade is a woody shrub or small tree growing up to $6 \mathrm{~m}$ in height in the Solanaceae family, and native to Mexico and Central America (Kumari, 2013). It was first introduced into Florida in the 1960s as an ornamental plant prized for its small flowers and brightly colored fruit, but escaped cultivation in Florida and other subtropical and tropical areas. In 2017, it was categorized as a Category 2 invasive plant by the FISC (Florida Exotic Plant Pest Council, 2019) because of its propensity to escape where it was originally planted. Twoleaf nightshade has been vouchered in over 20 counties in peninsular Florida and also in at least two counties in Texas [U.S. Department of Agriculture (USDA), 2021; Wunderlin et al., 2021 ]. It spreads by seed; these have a high viability rate and are dispersed by birds, which also increases the likelihood of spread (Brown et al., 2020 ). Once established, it can form thickets with trunks growing up to 3 $\mathrm{cm}$ or more in many different habitats. While it has been an occasional nuisance and has not yet altered native plant communities (Florida Exotic Plant Pest Council, 2019), it is spreading into new counties in Florida (Morgan and Overholt, 2005), and county extension agents in southwest Florida are asked to identify twoleaf nightshade about three times per month on average by landscape professionals (S.H. Brown, unpublished data).

Twoleaf nightshade has many unique identification characteristics that should make it easily identifiable in the field. First, fruit-bearing shoots are slightly angled at the nodes, which gives the plant a zigzagged appearance. It also has two unequally sized leaves on the same node, which is also unusual. Newly emerging flowers droop, while the fruit grow upright. The fruit are bright orange; and because the plant is in flower or fruit throughout most of the year, it should be easier to identify because distinct reproductive structures usually increase identification accuracy by laypersons (MacKenzie et al., 2017). The reason this plant is often the subject of identification requests is likely because of little awareness about the species. Additionally, it is morphologically like several other nightshade (Solanum) species in Florida, such as red soda apple (S. capsicoides) and jamaican nightshade ( $S$. jamaicense), the latter of which has no prickles similar to twoleaf nightshade, whereas the other four nightshade species in Florida have them. While fruiting shoots are easily distinguishable from other plants because of the two unequal leaves per node, leaves on nonfruiting shoots are less conspicuous, with simple alternate leaves with winged petioles that are 10 to $15 \mathrm{~cm}$ long and 3.5 to $6.5 \mathrm{~cm}$ wide, similar to many other plants (Fig. 3). Not much is known concerning management of twoleaf nightshade, thus research is needed to determine if the same methods that are effective for other nightshade species would be efficacious on twoleaf nightshade. Because it is spread via seed and is often problematic in landscape planting beds (which can limit postemergence options), information is needed on effective preemergence controls. As it is commonly either misidentified or its identity unknown, it would be prudent to include identification information in outreach materials to inform homeowners and green industry professionals of its potential impacts and to keep better informed of its distribution.

DAYFLOWERS AND SPIDERWORTS: INVASIVE GENERA THAT INCLUDE INNOCENT NATIVES. There are currently nine species of spiderwort that have been documented in Florida, of which four are considered native, including hairyflower spiderwort (Tradescantia hirsutiflora), ohio spiderwort ( $T$. obiensis), longleaf spiderwort (T. roseolens), and zigzag spiderwort (T. subaspera). All of these native species are typically confined to relatively small, defined areas in Florida-with the exception of ohio spiderwort, which is found throughout most of the state, 


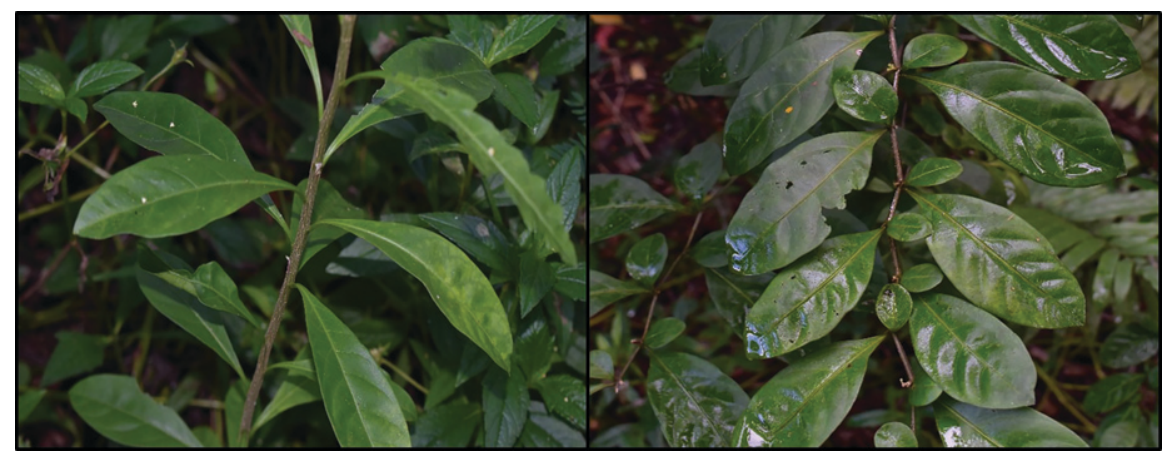

Fig. 3. Twoleaf nightshade nonfruiting (right) and fruiting (left) shoots. (Photo credit: Stephen H. Brown.)

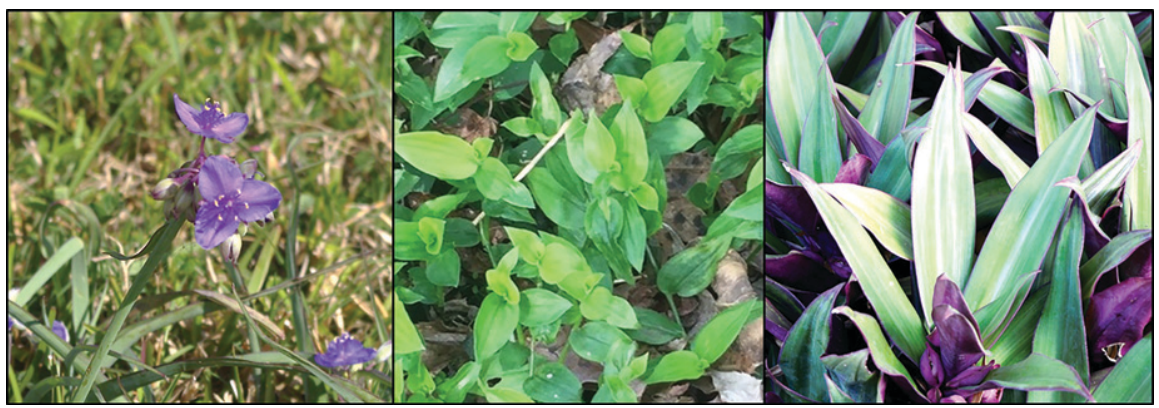

Fig. 4. Flowers of the Florida native ohio spiderwort (left) in comparison with invasive spiderwort species small-leaf spiderwort (center) and oysterplant (right). Ohio spiderwort is easily distinguishable from other invasive spiderwort species, but it has flowers that resemble certain dayflower species. (Photo credits: ohio spiderwort, Annette Chandler; small-leaf spiderwort, S. Christopher Marble; oysterplant, Stephen H. Brown.)

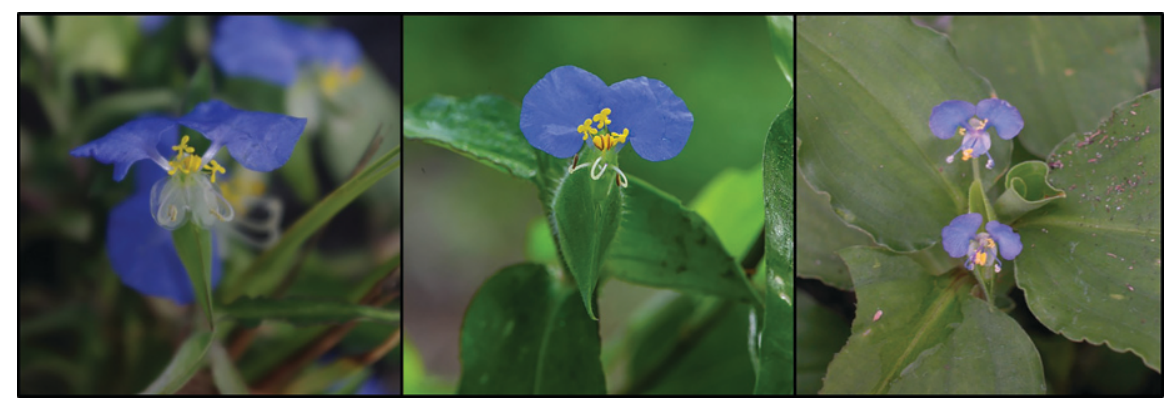

Fig. 5. Flowers of the Florida native whitemouth dayflower (left) in comparison with non-native common dayflower (center) and benghal dayflower (right). (Photo credits: whitemouth and benghal dayflowers, Annette Chandler; common dayflower, Roger L. Hammer.)

with the exception of the southernmost counties (Wunderlin et al., 2021). While ohio spiderwort is common and a widely distributed native, most of the literature has focused on the invasive species in this genus, namely small-leaf spiderwort ( $T . \mathrm{flu}^{-}$ minensis) and oysterplant (T. spathacea). Both small-leaf spiderwort and oysterplant are listed as Category 1 invasives by FISC (Florida Exotic Plant Pest Council, 2019) and have invaded sympatric with invasives (Tucker, 1989; Turner, 2006). Ohio spiderwort is easily distinguishable compared with the two most notable invasive species in Florida, small-leaf spiderwort and oysterplant (Fig. 4). Ohio spiderwort has a more upright and clumping growth habit, growing up to $1 \mathrm{~m}$ high, with long leaves reaching $15 \mathrm{~cm}$ in length, and has showy, bluish-purple flowers. Small-leaf spiderwort rarely grows above $15 \mathrm{~cm}$ in height, with shorter leaves, up to $8 \mathrm{~cm}$ long, and it has white flowers. Oysterplant can be easily identified by its elongated leaves that are green on the surface but purple underneath, and its sub-rosette growth habit.

Several native and introduced spiderwort species can also be confused with dayflower species, another widely distributed genus in Florida with both native and invasive members. The primary similarities between certain spiderwort and dayflower species (other than typical monocotyledonous features) are upright and clumping or spreading growth habits, succulent stems and foliage, and bluish-purple three-petal flowers throughout most of the year. These two genera can be distinguished by the number of stamens (spiderwort with six and dayflower with three) and the fact that dayflower has unequal-sized flower petals, among several other less obvious other traits (Tucker, 1989). Similar to spiderwort, dayflower can be difficult to identify in terms of individual dayflower species within the genus. There is also disagreement within the literature concerning the native status of several members, such as carolina dayflower (Commelina caroliniana) and common dayflower (C. diffusa var. diffusa), although most authors agree these species were introducedwhile whitemouth dayflower (C. erecta) and virginia dayflower (C. virginica) are native to Florida and the eastern United States (Faden, 1993).

Both native and introduced dayflower species can be problematic weeds in agricultural production, landscapes, and natural areas (Durham et al., 2016; Isaac et al., 2013). Several other dayflower species, such as asiatic dayflower (C. communis) and spreading dayflower (C. diffusa) (both introduced species) and whitemouth dayflower (C. erecta) (a native species) are frequently problematic in turfgrass, agricultural production, and other 
managed areas, both within and outside their native range (Isaac et al., 2013; Panigo et al., 2012). The most economically important dayflower species is benghal dayflower (C. benghalensis), which is a USDA federal noxious weed because of its prevalence and competition in field crops in California and throughout the southeastern United States (Fig. 5) (USDA, 2021). Notably, benghal dayflower is poorly controlled with glyphosate and many other postemergence herbicides, making management difficult. It spreads through both seed production (with some flowers being subterranean) and vegetatively by rooting along nodes, forming dense mats in fields (Webster et al., 2005). Because both native and non-native species of both genera can be problematic weeds in landscapes, agricultural production, and in other managed sites, along with natural areas, these species would be expected to be common targets of eradication efforts. While management would be needed regardless of native status in managed areas (Marble, 2018; Schnelle, 2019), misidentification in natural areas could lead to either misguided control efforts or delays in management, allowing small infestations to reach unmanageable levels (Standish, 2002). Due to the similarities among species within these genera, and the fact that many members of these genera are problematic, easyto-use field guides highlighting differences in native and non-native members would likely be useful for land managers and other stakeholders.

\section{Management implications and opportunities for improved outcomes}

Many other invasive plants can be confused with native species (or vice versa), and a full or even partially comprehensive list of common offenders would be exhaustive (Rawlins et al., 2018; Sarver et al., 2008). In Florida, notable invasive plants disguised as natives not previously mentioned would include skunkvine (Paederia foetida) and brazilian pepper, both of which are state-listed noxious weeds in Florida (Florida Department of State, 2021), along with lantana (Lantana strigocamara), which is a FISC Category 1 plant (Florida Exotic Plant Pest Council, 2019). Skunkvine can be confused with carolina jessamine ( $\mathrm{Gel}$ semium sempervirens) and many other native vines with opposite leaf arrangement when not in flower because of skunkvine's variable leaf morphology (Marble and Chandler, 2019). The key identification characteristic of brazilian pepper are compound leaves that are like native sumac (Rhus) species, and bright, showy berries and small white flowers that bear resemblance to dahoon holly (Ilex cassine var. cassine). Lantana can be especially difficult to differentiate between the invasive lantana (L. strigmocamara) and native species such as pineland lantana $(L$. depressa) because of similar leaf shapes, flower structures, and the fact that hybridizations have occurred among many lantana species in Florida (Wunderlin et al., 2021).

Misidentification can obviously cause significant management implications. First, there is a risk of mistakenly targeting native plant populations, especially in cases where morphologically similar native and invasive species inhabit the same locale. Research has shown that in some cases where invasives have yet to form dense monocultures, large-scale herbicide treatments can be more damaging to native plant populations than the invasive intruders (Rinella et al., 2009). When similar native and invasive plants coexist, managers might not know the area contains significant populations of native plants, which could cause elimination of those native populations and a vacuum that is more likely to be filled with the same or another invasive plant (Kettenring and Adams, 2011; Rinella et al., 2009). Second, when invasive plants are overlooked because of their resemblance to native plants, treatments will be delayed and populations can expand while being unnoticed.

Even in instances where control would be warranted regardless of native status, such as in agricultural production or managed landscapes, misidentification of genera (or even species or cultivar) can have negative consequences in terms of herbicide efficacy. Plant response to herbicides would be expected to be variable among plants in different families or genera, but there may be significant differences down to the species and cultivar levels, and even within different populations of the same species (Boutin and Rogers, 2000; Warwick, 1991). For example, dimethenamid provided effective control of bluemink but failed to control praxelis in preemergence herbicide trials in Florida (Khamare et al., 2020). Significant resources are devoted to invasive plant management every year (Hiatt et al., 2019). While most management efforts are typically directed toward large monoculture infestations and the species is known, there can be many instances where ineffective treatment protocols are implemented by private landowners and in smaller treatment areas because of misidentification.

There are several opportunities for improving invasive plant identification and management efforts. First, identification guides that include key identification characteristics for invasive plants (flowers, fruit, leaves, growth habit, etc.) could also include identification tools for similar native species, such as works by Rawlins et al. (2018) and Sarver et al. (2008). In cases where an invasive is commonly confused with several other nonnative or native plants, such as tree-ofheaven (Ailanthus altissima), which can be confused with black walnut ( $J u$ glans nigra), winged sumac (Rhus copallina), and several other native plants, simple identification keys useful by the layperson that use simple terminology and photos could also aid in improving identification (Brooks et al., n.d.). Volunteers and other nonprofessionals have been demonstrated to be accurate in identifying and mapping invasive species, but previous work has shown that identification accuracy is not equal for all species, and in many cases certain types of plants (e.g., grasses) or differentiating between different species within a genus can be more difficult (Jordan et al., 2012; Scott and Hallam, 2003). More research is needed to determine why certain species are harder to identifywhether it is based on similarity with other species, lack of distinct features, variability in appearance in different growth stages or environments, or other reasons. Second, in cases where the invasive has not formed a dense monoculture, control efforts such as spot-spraying, hack and squirt applications, basal applications, and similar targeted control efforts could be implemented (where feasible) to limit nontarget plant effects (Kettenring and Adams, 2011). Finally, a major hurdle in the management of invasive plants is 
simply awareness. The public predominately has negative views toward invasive plants, but they are not aware of specific invasive plant species (Daab and Flint, 2010; Potgieter et al., 2019). However, once informed, the public is more likely to remove an invasive plant in a landscape or remove it regardless of its ornamental appeal (Novoa et al., 2017). The challenge in educational efforts is that participation in training events, field days, and other educational opportunities is often composed of people already somewhat knowledgeable or at least interested in the subject matter, in this case, invasive plants (Cordeiro et al., 2020). Targeting educational efforts toward populations that have had little interaction with extension (or other educational and outreach) services could help increase awareness and knowledge of invasive plant issues (Clarke et al., 2019), while also increasing and broadening the clientele who rely on vetted, science-based information to inform their decisions (Telg et al., 2007). Because plants with invasive tendencies continue to be popular in the landscape industry for their ornamental benefits (Wirth et al., 2004), providing information on native or noninvasive ornamental alternatives (Knox et al., 2013), as well as breeding efforts to reduce invasive potential for the most popular species (Bechtloff et al., 2019; Deng et al., 2020; Freyre et al., 2012), will continue to be effective methods of reducing the effects of invasive plants.

\section{Conclusions}

Many common invasive plants are similar in appearance to native plants, which can lead to misidentification, especially with nonprofessionals who may be aiding in monitoring efforts. In some cases, a newly emerging invasive plant could also bear resemblance to common established invasive plants, delaying the detection of a new invader. Praxelis, twoleaf night shade, and multiple wild petunia, spiderwort, and dayflower species, among many others, are commonly misidentified due to their resemblance with other common plants or lack of unique identification characteristics. Plant identification errors can lead to inaccuracies in distribution maps and can also delay management, decreasing the success of control efforts and increasing costs. Invasive identification guides could be improved by including methods for differentiating invasive plants with their native lookalikes. Research to determine the most effective method of teaching plant identification to nonprofessional audiences could also help improve teaching methods and identification resources (websites, books, publications, etc.) to nonplant professionals. Finally, increasing the awareness of the impacts of invasive plants, especially within the public, can help mitigate the spread of invasive plants and increase acceptance of regulatory and management efforts.

\section{Literature cited}

Abbott, J.R., C.L. White, and S.B. Davis. 2008. Praxelis clematidea (Asteraceae), a genus and species new for the flora of North America. Bot. Res. Inst. Texas 2:621-626.

Alvarez, S. and D. Solis. 2018. Rapid response lowers eradication costs of invasive species: Evidence from Florida. Choices 33:1-9.

Anderson, M.C., H. Adams, B. Hope, and M. Powell. 2004. Risk assessment for invasive species. Risk Anal. 24:787-793, doi: 10.1111/j.0272-4332.2004.00478.x.

Bechtloff, A., C.R. Adams, S. Wilson, Z. Deng, and C. Wiese. 2019. Insights from southeastern US nursery growers guide research for sterile ornamental cultivars. J. Environ. Hort. 37:9-18, doi: 10.24266/ 0738-2898-37.1.9.

Bonter, D.N. and C.B. Cooper. 2012. Data validation in citizen science: A case study from project FeederWatch. Front. Ecol. Environ. 10:305-307, doi: 10.1890/ 110273.

Boutin, C. and C.A. Rogers. 2000. Pattern of sensitivity of plant species to various herbicides-An analysis with two databases. Ecotoxicology 9:255-271, doi: 10.1023/A:1026518027350.

Brandon, A., G. Spyreas, B. Molano-Flores, C. Carroll, and J. Ellis. 2003. Can volunteers provide reliable data for forest vegetation surveys? Nat. Areas J. 23:254-261.

Brooks, R., B. Bailey, and B. Sastre. n.d. Tree-of-heaven identification guide. Virginia Coop. Ext. Serv. Publ. SPES148NP. 19 Jan. 2021. <http://dendro. cnre.vt.edu/dendrology/factsheets.cfm $>$.

Brown, S.H., C. Marble, and S.F. Enloe. 2020. Distribution, identification, and management of two-leaf nightshade (Solanum diphyllum), an invasive plant in Florida. Univ. Florida Ext. Publ. ENH 1354. 3 Feb. 2021. <https://edis.ifas.ufl.edu/ep588>.
Clarke, M., Z. Ma, S. Snyder, and K. Floress. 2019. What are family forest owners thinking and doing about invasive plants? Landsc. Urban Plan. 188:80-92, doi: 10.1016/j.landurbplan.2018.10.024.

Cordeiro, B., H. Marchante, P. Castro, and E. Marchante. 2020. Does public awareness about invasive plants pays off? An analysis of knowledge and perceptions of environmentally aware citizens in Portugal. Biol. Invasions 22:2267-0081, doi: $10.1007 / \mathrm{s} 10530-020-02247-\mathrm{z}$.

Corlett, R.T. and J.C. Shaw. 1995. Praxelis clematidea: Yesterday South America, today Hong Kong, tomorrow the world? Mem. Hong Kong Nat. Hist. Soc. 20: 235-236.

Crall, A.W., C.S. Jarnevich, N.E. Young, B.J. Panke, M. Renz, and T.J. Stohlgren. 2015. Citizen science contributes to our knowledge of invasive plant species distributions. Biol. Invasions 17:2415-2427, doi: 10.1007/s10530-015-0885-4.

Crooks, J. and M.E. Soule. 1996. Lag times in population explosions of invasive species: Causes and implications, p. 39 46. In: O.T. Sandlund, P.J. Schei, and A. Viken (eds.). Proc. Norway/UN Conf. Alien Species. Norwegian Inst. Nat. Res., Trondheim, Norway.

Daab, M.T. and C.G. Flint. 2010. Public reaction to invasive plant species in a disturbed Colorado landscape. Invasive Plant Sci. Manag. 3:390-401, doi: 10.1614/ IPSM-D-09-00047.1.

Daehler, C.C. 2009. Short lag times for invasive tropical plants: Evidence from experimental plantings in Hawaii. PLoS One 4(2):e4462, doi: 10.1371/journal.pone. 0004462

Deng, Z., S.B. Wilson, X. Ying, C. Chen, R. Freyre, V. Zayas, and D.M. Czarnecki. 2020. 'UF-1013-1': An infertile cultivar of Lantana camara. HortScience 55: 953-958, doi: 10.21273/HORTSCI149 11-20.

Diagne, C., B. Leroy, R.E. Gozlan, A.C. Vaissieere, C. Assailly, L. Nuninger, D. Roiz, F. Jourdain, I. Jaric, and F. Courchamp. 2020. InvaCost, a public database of the economic costs of biological invasions worldwide. Sci. Data 7:277, doi: 10.1038/ s41597-020-00586-z.

Durham, M., P. Devkota, J. Ferrell, and B. Sellers. 2016. Spiderwort control in hay fields and pastures. Univ. Florida Ext. Publ. AGR 404. 19 Jan. 2021. <http:// edis.ifas.ufl.edu/ag407>.

El-Barougy, R., J.S. Maclvor, C.A. Arnillas, R.M. Nada, A.A. Khedr, and M.W. Codotte. 2020. Richness, phylogenetic diversity, and abundance all have positive effects on invader performance in an arid 
ecosystem. Ecosphere 11:e03045, doi: 10. $1002 / \mathrm{ecs} 2.3045$.

Faden, R.B. 1993. The misconstrued and rare species of Commelina (Commelinaceae) in the eastern United States. Ann. Mo. Bot. Gard. 80:208-218, doi: 10. $2307 / 2399824$.

Florida Department of State. 2021. Rule chapter 5B-57.007: Introduction or release of plant pests, noxious weeds, arthropods, and biological control agents. 28 Feb. 2021. <https://www.flrules.org/ Gateway/view_notice. asp? $\mathrm{id}=23639596>$.

Florida Exotic Plant Pest Council. 2019. List of invasive plant species. 14 Mar. 2021. <https://www.fleppc.org/list/list.htm>.

Foxcroft, L.C., D.M. Richardson, and J.R. Wilson. 2008. Ornamental plants as invasive aliens: Problems and solutions in Kruger National Park, South Africa. Environ. Manage. 41:32-51, doi: 10.1007/ s00267-007-9027-9.

Freyre, R., A. Moseley, S.B. Wilson, and G.W. Knox. 2012. Breeding and evaluating for landscape performance and fruitlessness in mexican petunia (Ruellia, Acanthaceae). HortScience 47:1245-1251, doi: 10.21273/ HORTSCI.47.9.1245.

Freyre, R. and E. Tripp. 2014. Artificial hybridization between U.S. native Ruellia caroliniensis and invasive Ruellia simplex: Crossability, morphological diagnosis, and molecular characterization. HortScience 49:991-996, doi: 10.21273/HORTSCI. 49.8.991.

Gardner, A.G. and K.A. Williges. 2015. Praxelis clematidea (Asteraceae): A new plant invader of Florida. Southeast. Nat. 14:21-27.

Heckman, R.W., F.W. Halliday, P.A. Wilfahrt, and C.E. Mitchell. 2017. Effects of native diversity, soil nutrients, and natural enemies on exotic invasion in experimental plant communities. Ecology 98:14091418, doi: 10.1002/ecy.1796.

Hiatt, D., K. Serbesoff-King, D. Lieurance, D.R. Gordon, and S.L. Flory. 2019. Allocation of invasive plant management expenditures for conservation: Lessons from Florida, USA. Conserv. Sci. Pract. 1:e51, doi: $10.1111 / \operatorname{esp} 2.51$.

Holzmueller, E.J. and S. Jose. 2009. Invasive plant conundrum: What makes aliens so successful? J. Trop. Agr. 47:18-29, doi: 10.1006/anbo.1996.0117.

Isaac, W.A., G. Zongjun, and M. Li. 2013. Managing Commelina species: Prospects and limitations, p. 543-562. In: A.J. Price and J.A. Kelton (eds.). HerbicidesCurrent research and case studies in use. IntechOpen, London, UK, doi: 10.5772/ 55842 .
Jordan, R.C., W.R. Brooks, D.V. Howe, and J.G. Ehrenfeld. 2012. Evaluating the performance of volunteers in mapping invasive plants in public conservation lands. Environ. Manage. 49:425-434, doi: 10. 1007/s00267-011-9789-y.

Keane, R.M. and M.J. Crawley. 2002. Exotic plant invasions and the enemy release hypothesis. Trends Ecol. Evol. 17:164-170, doi: $\quad 10.1016 / S 0169-5347 \% 2802 \% 2902$ 499-0.

Kettenring, K.M. and C.R. Adams. 2011. Lessons learned from invasive plant control experiments: A systematic review and meta-analysis. J. Appl. Ecol. 48:970-979, doi: 10.1111/j.1365-2664.2011.01979.x.

Khamare, Y., S.C. Marble, N.S. Boyd, and S.T. Steed. 2020. Pre and post control of Praxelis clematidea, an emerging weed in Florida nursery production. Weed Technol. 34:779-786, doi: 10.1017/ wet.2020.53.

King, R.M. and H. Robinson. 1970. Studies in the Eupatorieae (Compositae). XXVIII. The genus Praxelis. Phytologia 20:193-195.

Kleunen, M.V., E. Weber, and M. Fischer. 2010. A meta-analysis of trait differences between invasive and non-invasive plant species. Ecol. Lett. 13:235-245, doi: 10. 1111/j.1461-0248.2009.01418.x.

Knox, G.W., S.B. Wilson, Z. Deng, and R. Freyre. 2013. Alternatives to invasive plants commonly found in central Florida landscapes. Univ. Florida Ext. Publ. ENH 1207. 2 Feb. 2021. <https://edis.ifas.ufl. edu/ep468>.

Kumari, M.R. 2013. Solanum diphyllum (Solanaceae) - A new record for southern India. Rheedea 23:50-51.

Langeland, K.A. 1996. Hydrilla verticillata (L.F.) Royle, "The perfect aquatic weed. S. Appalachian Bot. Soc. 61:293304

Laroche, R.B. and A.P. Ferriter. 1992. The rate of expansion of melaleuca in south Florida. J. Aquat. Plant Manage. 30:62-65.

Liu, G.Y.B.Y. and Z.H. Zhu. 2018. Elevated nitrogen allows the week invasive plant Galinsoga quadriradiata to become more vigorous with respect to inter-specific competition. Sci. Rep. 8(3136), doi: 10.1038/s41598-018-21546-z.

Long, R.W. and L.J. Uttal. 1962. Some observations on flowering in Ruellia (Acanthaceae). Rhodora 64:200-206.

Mack, R.N., D. Simberloff, W.M. Lonsdale, H. Evans, M. Clout, and F.A. Bazzaz. 2000. Biotic invasions: Causes, epidemiology, global consequences, and control. Ecol. Appl. 10:689-710, doi:
10.1890/1051-0761(2000)010[0689:BICEGC]2.0.CO;2.

MacKenzie, C.D., G. Murray, R. Primack, and D. Weihrauch. 2017. Lessons from citizen science: Assessing volunteer-collected plant phenology data with Mountain Watch. Biol. Conserv. 208:121-126, doi: 10.1016/j.biocon.2016.07.027.

Marble, S.C. 2018. Native weedy pests of the deep south. HortScience 53:1244 1249, doi: 10.21273/HORTSCI13112-18.

Marble, S.C. and A. Chandler. 2019. Control of skunk-vine (Paederia foetida L.) with preemergence and postemergence herbicides in central Florida during the winter season. Invasive Plant Sci. Manag. 12:51-59, doi: 10.1017/inp.2019.1.

Maxwell, B.D., E. Lehnhoff, and L.J. Rew. 2009. The rationale for monitoring invasive plant populations as a crucial step for management. Invasive Plant Sci. Manag. 2:1-9, doi: 10.1614/IPSM-07-054.1.

Morgan, E.C. and W.A. Overholt. 2005. New records of invasive exotic plant species in St. Lucie County, Florida. Castanea 70: 59-62, doi: 10.2179/0008-7475(2005) 070[0059:NROIEP]2.0.CO;2.

Novoa, A., K.D. Schmutz, J. Fried, and G. Vimercati. 2017. Does public awareness increase support for invasive species management? Promising evidence across taxa and landscape types. Biol. Invasions 19:3691-3705, doi: 10.1007/s10530017-1592-0.

Osland, M.J. and L.C. Feher. 2020. Winter climate change and the poleward range expansion of a tropical invasive tree (brazilian pepper-Schinus terebinthifolius). Glob. Change Biol. 26:607-615, doi: 10.1111/ gcb.14842.

Oxley, F., T.M. Waliczek, and P. Williamson. 2016. Stakeholder opinions of invasive species and their management in the San Marcos River. HortTechnology 26:514-521, doi: 10.21273/ HORTTECH.26.4.514.

Overholt, W., J.P. Cuda, and L. Markle. 2012. Can novel weapons favor native plants? Allelopathic interactions between Morella cerifera (L.) and Schnius terebinthifolia Raddi. J. Torrey Bot. Soc. 139:356-366, doi: 10.3159/TORREY-D-11-00057.1.

Panetta, F.D. and J. McKee. 1997. Recruitment of the invasive ornamental, Schinus terebinthifolius, is depend upon frugivores. Austral. J. Ecol. 22:432-438, doi: 10.1111/ j.1442-9993.1997.tb00694.x.

Panigo, E.S., I.M. Dellaferrera, J.M. Acosta, A.G. Bender, J.I. Garetto, and M.G. Perreta. 2012. Glyphosate-induced structural variations in Commelina erecta $\mathrm{L}$. (Commelinaceae). Excotoxicology 
Environ. Safety 76:135-142, doi: 10.1016/j.ecoenv.2011.10.002.

Papp, L., B. Leeuwen, P. Szilassi, Z. Tobak, J. Szatmari, M. Arvai, J. Meszaros, and L. Pasztor. 2021. Monitoring invasive plant species using hyperspectral remote sensing data. Land 10:29, doi: 10.3390/land 10010029 .

Pemberton, R.W. and A.P. Ferriter. 1998. Old world climbing fern (Lygodium microphyllum), a dangerous invasive weed in Florida. Amer. Fern J. 88:165-175.

Petitpierre, B., O. Broennimann, C. Kueffer, C. Daehler, and A. Guisan. 2017. Selecting predictors to maximize the transferability of species distribution models: Lessons from cross-continental plant invasions. Glob. Ecol. Biogeogr. 26:275-287, doi: $10.1111 /$ geb.12530.

Pimentel, D., R. Zuniga, and D. Morrison. 2005. Update on the environmental and economic costs associated with alieninvasive species in the United States. Ecol. Econ. 52:273-288, doi: $10.1016 / \mathrm{j} . \mathrm{ecol}$ econ.2004.10.002.

Potgieter, L.J., M. Gaertner, P.J. O'Farrell, and D.M. Richardson. 2019. Perceptions of impact: Invasive alien plants in the urban environment. J. Environ. Manage. 229:76-87, doi: 10.1016/j.jenvman. 2018.05.080.

Pysek, P., V. Jorosik, P.E. Hulme, J. Pergl, M. Hejda, U. Schaffner, and M. Vila. 2012. A global assessment of invasive plant impacts on resident species, communities and ecosystems: The interaction of impact measures, invading species' traits and environment. Glob. Change Biol. 18: 1725-1737, doi: 10.1111/j.1365-2486. 2011.02636.x.

Randall, J.M., L.E. Morse, N. Benton, R. Hiebert, S. Lu, and T. Killeffer. 2008. The invasive species assessment protocol: A tool for creating regional and national lists of invasive nonnative plants that negatively impact biodiversity. Invasive Plant Sci. Manag. 1:36-49, doi: 10.1614/ IPSM-07-020.1.

Rawlins, K.A., R.L. Winston, C.T. Bargeron, D.J. Moorhead, and R. Carroll. 2018. New invaders of the southeast. U.S. Dept. Agr., For. Serv., Forest Health Assess. Appl. Sci. Team, Morgantown, WV.

Rejmanek, M. and D.M. Richardson. 1996. What attributes make some plant species more invasive? Ecology 77:1655-1661, doi: $10.2307 / 2265768$.

Ren, M.X. and Q.G. Zhang. 2009. The relative generality of plant invasion mechanisms and prediction future invasive plants. Weed Res. 49:449-460, doi: 10. $1111 /$ j.1365-3180.2009.00723.x.

Rinella, M.J., B.D. Maxwell, P.K. Fay, T. Weaver, and R.L. Sheley. 2009. Control efforts exacerbates invasive-species problem. Ecol. Appl. 19:155-162, doi: 10. 1890/07-1482.1.

Rodgers, L., T. Pernas, J. Redwine, B. Shamblin, and S. Bruscia. 2017. Multiscale invasive plant monitoring: Experiences from the greater Everglades restoration area. Weed Technol. 32:11-19, doi: 10. 1017/wet.2017.106.

Royimani, L., O. Mutanga, J. Odindi, T. Dube, and T.N. Mantongera. 2019. Advancements in satellite remote sensing for mapping and monitoring of alien invasive plant species (AIP). Phys. Chem. Earth 112:237-245, doi: 10.1016/j.pce.2018. 12.004 .

Sarver, M., A. Treher, L. Wilson, R. Naczi, and F.B. Kuehn. 2008. Mistaken identity? Invasive plants and their native look-alikes. 2 Feb. 2021. <https://www.nrcs.usda.gov/ Internet/FSE_DOCUMENTS/nrcs144 p2_024329.pdf $>$.

Schnelle, M.A. 2019. Native woody plants of the southern United States with weedy or invasive tendencies: A review of common offenders. HortTechnology 29: 567-570, doi: 10.21273/HORTTECH 04334-19.

Scott, W.A. and C.J. Hallam. 2003. Assessing misidentification rates through quality assurance of vegetation monitoring. Plant Ecol. 165:101-115, doi: 10. 1023/A:1021441331839.

Standish, R.J. 2002. Experimenting with methods to control Tradescantia fluminensis, an invasive weed of native forest remnants in New Zealand. N. Z. J. Bot. 26:161-170.

Telg, R., T. Irani, A. Hurst, and M. Kistler. 2007. Local marketing and promotional efforts of Florida extension agents. J. Ext. 45(2):2FEA5. 21 Jan. 2021. <https:// www.joe.org/joe/2007april/a5.php $>$.

Tucker, G.C. 1989. The genera of Commelinaceae in the southeastern U.S. J. Arnold Arboretum 70:97-130.

Turner, B.L. 2006. Texas species of Tradescantia (Commelinaceae). Phytologia 88 : 312-331, doi: 10.5962/bhl.part.10459.

Turner, C.E., T.D. Center, D.W. Burrows, and G.R. Buckingham. 1998. Ecology and management of Melaleuca quinquenervia, an invader of wetlands in Florida, U.S.A. Wetlands Ecol. Manage. 5:165-178, doi: 10.1023/A:1008205122757.
U.S. Department of Agriculture. 2021. The PLANTS database. 18 Jan. 2021. $<$ http://plants.usda.gov $>$.

VanWallendael, A., E. Hamann, and S.J. Franks. 2018. Evidence for plasticity, but not local adaptation, in invasive Japanese knotweed (Reynoutria japonica) in North America. Evol. Ecol. 32:395-410, doi: 10.1007/s10682-018-9942-7.

Verloove, F. 2010. Invaders in disguise: Conservation risks derived from misidentification of invasive plants. Manage. Biol. Invasions $\mathrm{l}(\mathrm{l}): \mathrm{l}-5$, doi: $10.3391 / \mathrm{mbi} .2010$. 1.1.02.

Villamagna, A.M. and B.R. Murphy. 2010. Ecological and socio-economic impacts of invasive water hyacinth (Eichhornia crassipes): A review. Freshwater Biol. 55:282-298, doi: 10.1111/j.1365-2427. 2009.02294.x.

Waliczek, T.M., K. Parsley, P.S. Williamson, and F.M. Oxley. 2018. Curricula influence college student knowledge and attitudes regarding invasive species. HortTechnology 28:548-556, doi: 10.21273/HORTTECH 03979-18.

Ward, D.B. 2007. Keys to the flora of Florida-17, Ruellia (Acanthaceae). Phytologia 89:293-299.

Warwick, S.I. 1991. Herbicide resistance in weedy plants: Physiology and population biology. Annu. Rev. Ecol. Syst. 22: 95-114.

Waterhouse, B.M. 2003. Know your enemy: Recent records of potentially serious weeds in northern Australia, Papua New Guinea, and Papua (Indonesia). Telopea 10: 477-485, doi: 10.7751/telopea20035624.

Webster, T.M., M.G. Burton, A.S. Culpepper, A.C. York, and E.P. Prostko. 2005. Tropical spiderwort (Commelina benghalensis): A tropical invader threatens agroecosystems of the southern United States. Weed Technol. 19:501-508, doi: 10.1614/WT-04-234R.1.

Weidlich, E.W.A., F.G. Florido, T.B. Sorrini, and P.H.S. Brancalion. 2020. Controlling invasive plant species in ecological restoration: A global review. J. Appl. Ecol. 57:1806-1817, doi: 10.1111/1365-2664. 13656.

Wickert, K.L., E.S. O’Neal, D.D. Davis, and M.T. Kasson. 2017. Seed production, viability, and reproductive limits of the invasive Ailanthus altissima (tree-of-heaven) within invaded environments. Forests 8(7):226, doi: 10.3390/f8070226.

Wiese, C., C.R. Adams, and A.M. Smith. 2013. Experimental research informs control of Mexican petunia (Ruellia simplex) 
in natural areas and home-gardens. Proc. Florida Hort. Soc. 126:332-337.

Wirth, F.F., K.J. Davis, and S.B. Wilson. 2004. Florida nursery sales and economic impacts of 14 potentially invasive landscape species. J. Environ. Hort. 22:
12-16, doi: 10.24266/0738-289822.1.12.

Wilson, S.B., P.C. Wilson, and J.A. Albano. 2004. Growth and development of the native Ruellia caroliniensis and invasive Ruellia tweediana. HortScience 39:
1015-1019, doi: 10.21273/HORTSCI. 39.5.1015.

Wunderlin, R.P., B.F. Hansen, A.R. Franck, and F.B. Essig. 2021. Atlas of Florida plants. 21 Dec. 2020. <http://florida. plantatlas.usf.edu/>. 